\title{
Trifurcation of Recurrent Laryngeal Nerve: A Case Report
}

\author{
Üç Dallı Rekürren Laringeal Sinir: Bir Olgu Sunumu
}

\author{
๑ Mehmet Uluşahin, ๑ Arif Burak Çekiç, ๑ Muhammed Selim Bodur, ๑ Kadir Tomas, \\ (1) Mithat Kerim Arslan \\ Karadeniz Technical University Faculty of Medicine Farabi Hospital, Department of General Surgery, Trabzon, Turkey
}

\begin{abstract}
Nowadays, thyroidectomy is a frequently performed type of surgery. Although thyroid operations are generally performed without complications, there may be many anatomic variation and complications related with them. Recurrent laryngeal nerve (RLN) paralysis is a frightening complication of thyroid surgery. For preventing this complication, having a good knowledge and experience about this small anatomic region is necessary. In this paper, we present a case of RLN variation identified in a 36-year-old female patient with multinodular goiter. Thyroidectomy was decided after examinations performed due to palpable swelling in the neck, then, three-branched left RLN was found after proper dissection and preserved during thyroidectomy operation. No complication was observed in the postoperative period and the patient was discharged next day.
\end{abstract}

Keywords: Recurrent laryngeal nerve, trifurcation, thyroidectomy, anatomic variation, nerve injury
Öz

Tiroidektomi günümüzde sık olarak uygulanan bir ameliyat çeşididir. Tiroidektomi operasyonları genel olarak komplikasyonsuz sonlanmakla beraber birçok anatomik varyasyon ve bunların neden olduğu komplikasyonlar ile karşılaşılabilir. Rekürren laringeal sinir (RLS) felci tiroid cerrahisinin korkutucu bir komplikasyonudur. Bu komplikasyondan kaçınmak için çok çeşitli varyasyonları içinde bulunduran bu küçük anatomik bölgeye hakim olmak ve yeterli tecrübeye sahip olmak gerekir. Biz bu yazıda 36 yaşında multinodüler guatrlı bir kadın hastada tespit edilen RLS varyasyonunu takdim ettik. Bahsedilen hastada boyunda ele gelen şişlik sonrası yapılan tetkikler neticesinde tiroidektomi kararı verildi ve tiroidektomi operasyonu sırasında tespit edilen üç dallı sol RLS uygun diseksiyon ile bulundu ve korundu. Postoperatif dönemde hastanın komplikasyonu olmadı ve ertesi gün taburcu edildi.

Anahtar Sözcükler: Rekürren laringeal sinir, trifurkasyon, tiroidektomi, anatomik varyasyon, sinir hasarı

\section{Introduction}

Nowadays, thyroidectomy is frequently performed due to benign and malign reasons. These operations are important due to involvement of many anatomic variations (1). Complications may occur even if the operations are performed by surgeons with adequate experience and thorough knowledge of the anatomy of the recurrent laryngeal nerve (RLN) and its anatomical variations. For preventing nerve injury, many studies have been performed and proper dissection techniques have been suggested (2). Additionally, technology has been advanced in this area and a system like intraoperative nerve monitoring (IONM) was introduced for helping surgeons identify the nerve. RLN injury is still a challenge for many surgeons even with adequate experience and use of IONM. In this case report, we present a threebranched left RLN variation identified in a female patient who underwent thyroidectomy operation.

\section{Case}

A 36-year-old female patient living in an endemic goiter region without additional complaint was admitted to the general surgery outpatient clinic at our hospital due to a palpable swelling in the neck. Vital signs were normal. She had no complaint except swelling. In physical examination, a palpable nodule measuring $2 \mathrm{~cm}$ in diameter was identified in the right side.

Thyroid hormones and free thyroxine levels were normal. Ultrasonography of the neck showed solitary
Address for Correspondence/Yazışma Adresi: Mehmet Uluşahin

Karadeniz Technical University Faculty of Medicine Farabi Hospital, Department of General Surgery, Trabzon, Turkey

Phone: +90 5063713443 E-mail: ulusahinmehmet@hotmail.com ORCID ID: orcid.org/0000-0002-0212-2103 Received/Geliş Tarihi: 23 June 2017 Accepted/Kabul Tarihi: 22 September 2017
${ }^{10}$ Copyright 2018 by The Medical Bulletin of University of Health Sciences Haseki Training and Research Hospital
The Medical Bulletin of Haseki published by Galenos Yayinevi.

Telif Hakkı 2018 Sağlik Bilimleri Üniversitesi Haseki Eğitim ve Araştırma Hastanesi Haseki Tıp Bülteni, Galenos Yayınevi tarafından basılmıştır. 
and hypoechoic nodules sized $22 \mathrm{~mm}$ and $13 \mathrm{~mm}$ in the right with increased vascularity and no pathologic lymph node. Fine needle aspiration biopsy was performed twice and revealed atypia of undetermined significance. Total thyroidectomy was done. In exploration, RLNs were identified in the tracheoesophageal groove after two dissections performed on each side at the level of inferior thyroid artery (ITA). It was found that RLN on the left side was divided into three branches at a distance of $10 \mathrm{~mm}$ to Berry's ligament (Figure 1). Nerves were preserved after carefully dissecting and the operation was completed after performing total thyroidectomy. The patient was discharged at first postoperative day without any complication. Pathological analysis revealed multinodulary goiter. There was no thyroid hormone abnormality during follow-up.

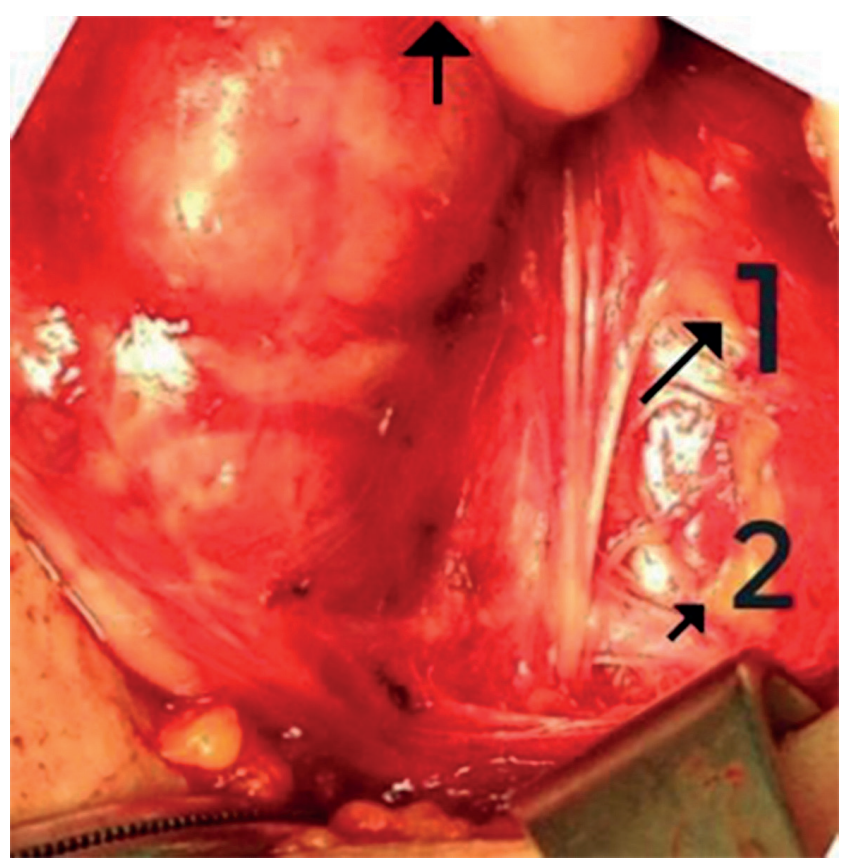

Figure 1. Operation image of three-branched recurrent laryngeal nerve (Black arrow: showing cranial part, 1: three-branched recurrent laryngeal nerve; 2 : inferior thyroid artery)

\section{Discussion}

Nowadays, thyroidectomy operation is a frequently performed kind of operation. It is a fact that many patients undergo this operation without any complications, however, even very experienced surgeons may face difficulties in some cases. Parathyroid gland injury, vessel injury and related intraoperative/postoperative bleedings, trachea and esophagus injuries, and nerve injury are leading complications during thyroidectomy. RLN injury may be considered as a challenge for surgeons. This complication may be life-threatening and even mortal.
Most important reason complicating thyroid gland surgery for even experienced surgeons is anatomic variations which may be encountered during thyroid surgery. More than 30 variations related with RLN have been reported $(3,4)$.

In normal anatomy of the RLN, the right RLN goes upward after turning right the subclavian artery from back to front and it continues its course through upward after crossing the ITA near the tracheoesophageal groove. It enters into the larynx after penetrating the cricothyroid membrane behind the right lobe of the thyroid gland. Also, the left RLN encircles the aortic arch at the ductus arteriosus and after separated from the vagus nerve and enters into the larynx like right one after advancing upwards through the tracheoesophageal groove. Very few nerves may be behind or front of the tracheoesophageal groove $(4,5)$.

Visible anatomic variations can be defined as extralaryngeal branches like non-recurrent nerve or bifurcations/trifurcations and extension of the RLN through ITA $(1,3)$. In previous studies, extralaryngeal branches have been reported with prevalence between 30\% and $70.6 \%(2,5,6)$. All variations including bifurcations and trifurcations are more frequent in the right side (6). Especially RLN trifurcation is much rarer than bifurcation. The rate of trifurcation has been reported to be $0.9 \%$ in a series involving 2626 nerve dissections (5). Extralaryngeal branches are not always seen in the same location. Generally, it has been reported to be $0.6-4 \mathrm{~cm}$ below the cricoid cartilage as it was in our case (5). Rarely, RLN may course differently as non-recurrent nerve separated from the vagus nerve at the upper part. Non-recurrent nerve is more frequent in the right side like other variations as previously mentioned, and its prevalence rate is 0.3 $1.6 \%(2,4)$. Anatomic relationship between the RLN and ITA must also be known. RLN may be in front or behind of the ITA or between branches of the artery. Prevalence rate is different for the right and left sides. The prevalence has been reported by Ardito et al. (5) as 12\% and 1.9\% for anterior placement, $61 \%$ and $77.4 \%$ for posterior placement and $27 \%$ and $20.5 \%$ for placement between arterial branches in the right and left sides, respectively.

Although RLN anatomy and variations have been extensively researched and described, the overall incidence of permanent and transient RLN paralysis have been reported to be $1-2 \%$ and $5-6 \%$, respectively $(2,7)$. Clamping, thermal effect, inappropriate dissection and ligation can be considered as the main reasons of nerve injury (2).

Although some surgeons avoid routine nerve dissections, it has been suggested and used for identifying variations and avoiding nerve injury by many surgeons (2). 
Identifying variations in preoperative period is not possible (2). The RLN is generally visible near ITA or entrance into Berry's ligament by dissection (6). We suggest that nerve dissection must be started distally and go upward from there without ligating the vessel before identifying the nerve $(2,8)$. IONM method has been introduced to the medical field in order to reduce the rate of nerve injury and it is safely utilized in many centers (2). However, cost of IONM is not covered for many indications by the health care insurance in Turkey. Therefore, we cannot routinely use this method.

In conclusion, RLN injury is an important complication of thyroid surgery. Anatomic variations like three-branched $R L N$ in this region may cause nerve injury if they cannot be recognized. Surgeons performing thyroid gland operations must know the RLN anatomy and variations and should have adequate experience for recognizing these variations when encountered intraoperatively.

\section{Ethic}

Informed Consent: It was taken.

Peer-review: Externally peer-reviewed.

\section{Authorship Contributions}

Surgical and Medical Practices: M.U., M.K.A. Concept: M.U., M.S.B. Design: M.U., M.K.A. Data Collection or Processing: M.U., A.B.Ç., M.S.B., K.T. Analysis or Interpretation: M.U., A.B.Ç., M.S.B., K.T., M.K.A. Literature Search: M.U., A.B.Ç., K.T. Writing: M.U.

Conflict of Interest: No conflict of interest was declared by the authors.
Financial Disclosure: The authors declared that this study received no financial support.

\section{References}

1. Gurleyik E. Three variations of the laryngeal nerve in the same patient: a case report. J Med Case Rep 2011;5:266.

2. Chiang FY, Lu IC, Chen HC, et al. Anatomical variations of recurrent laryngeal nerve during thyroid surgery: how to identify and handle the variations with intraoperative neuromonitoring. Kaohsiung J Med Sci 2010;26:575-83.

3. Manoğlu B, Yılmaz EM, Erdoğan A, Özkan MB, Özçiftci VM. Report of a rare case: Double recurrent laryngeal nerve. Ulus Cerrahi Derg 2016;32:298-9.

4. Skandalakis JE, Skandalakis PN, Skandalakis LJ. Cerrahi anatomi ve teknik. İkinci baskı, İstanbul, Nobel Tıp Kitapevi, 2000.

5. Ardito G, Revelli L, D'Alatri L, Lerro V, Guidi ML, Ardito F. Revisited anatomy of the recurrent laryngeal nerves. Am J Surg 2004;187:249-53.

6. Beneragama T, Serpell JW. Extralaryngeal bifurcation of the recurrent laryngeal nerve: a common variation. ANZ I Surg 2006;76:928-31.

7. Beldi G, Kinsbergen T, Schlumpf R. Evaluation of intraoperative recurrent nerve monitoring in thyroid surgery. World I Surg 2004;28:589-91.

8. Makay O, Icoz G, Yilmaz M, Akyildiz M, Yetkin E. The recurrent laryngeal nerve and the inferior thyroid arteryanatomical variations during surgery. Langenbecks Arch Surg 2008;393:681-5. 